International Journal of Engineering \& Technology, 7 (4.3) (2018) $545-549$
International Journal of Engineering \& Technology
SPC
Website: www.sciencepubco.com/index.php/IJET
Research paper

\title{
Innovation as a Factor of the Development of Territorial Communities
}

\author{
V.V. Varuk ${ }^{1 *}$, A.O. Kramarenko ${ }^{1}$, V.A. Lunova ${ }^{1}$, O.S. Parkhomenko ${ }^{1}$ \\ ${ }^{1}$ V.N. Karazin Kharkiv National University, Ukraine \\ *Corresponding author E-mail: \\ *Corresponding author E-mail: varuk@karazin.ua
}

\begin{abstract}
The purpose of the paper is to substantiate the need for the introduction of innovations in the activities of business entities and territorial communities. Analyzing, systematizing and generalizing the scientific work of many researchers, it was discovered that innovation is one of the factors of successful decentralization. As a result of the study, the essence of the concept of innovation is shown, which can be considered as the introduction of something "new and improved" or activity that requires a person or community to do something different than before. Elements of innovation capacity are singled out. The peculiarities of investment activity formation in Ukraine are outlined. The basic principles and functions of management of effective work in the field of innovations are determined. The factors of implementation of innovations in the branches, organizations and territorial communities are presented.
\end{abstract}

Keywords: Development; Innovation; Innovation activity; Innovation capacity; Territorial communities; Welfare.

\section{Introduction}

Globalization, which became one of the decisive characteristics of the global economy at the end of the 20th and the beginning of the 21 st century, has set before the governments of many countries the problem of finding new forms and methods of adapting the national economic, political and legal environment to the current requirements for the implementation of economic relations. The rapid changes of the factors, which determine competitiveness in world markets, the dynamic development of the global environment, make governments, in shaping the conditions for economic growth, to more actively address the problems of ensuring national competitiveness on a global scale. That is why the research of innovative processes that are the driving force behind the development of business entities deserves special attention and defines the strategic future of the entire country.

\section{Main Body}

Some aspects of innovation have been researched in the work of A. Smith "Research on the nature and causes of wealth of peoples" when considering the growth of income and welfare of people. The factor that provides income growth of peoples is the social division of labor, which was considered by him as an economic innovation [13].

The study of the essence of innovation is also found in the theories of D. Ricardo, K. Marx in studying them scientific, technical and organizational improvements [11]. However, it should be noted that in these concepts, the effect of innovation was considered in combination with other factors and almost neglected in evolutionary models of economic development. The emergence of an independent innovation theory occurred at the beginning of the twentieth century. in the writings of such prominent economists as
V. Sombart and I. Schumpeter $[9,12]$. The prominent Ukrainian scientist M. Tugan-Baranovskaya was in the origins of the innovative theory of economic development and, on the basis of the analysis, came to the conclusion: not consumption and demand manage production, namely production manages consumption, and this is due to the accumulation of capital and its investment in new technologies and production [17].

In the scientific literature, innovation is defined as a sociotechnical economic process, which through the practical use of ideas and inventions leads to the creation of the best in their properties of products, technologies the emergence of which in the market can bring added profit. On the other hand, innovation is the use of new ideas, goods, services, materials, technologies immediately after the discovery or creation of an invention in order to improve production, methods of its production and distribution [15].

The Law of Ukraine "On Innovation Activity" determined that Innovations are newly created (applied) and / or improved competitive technologies, products or services, as well as organizational and technical decisions of an industrial, administrative, commercial or other nature that significantly improve the structure and quality of production and / or social sphere [7].

Innovations that have proven successful in one industry, organization or community can be a source of inspiration for another. However, they need to be adapted and modified to maximize the potential of the relevant field of activity or area where they hope to be reproduced. That is, each innovation has two parts: the first one is the invention of the object itself and the second is the preparation of expectations, so that when the invention comes up, it looks both new and familiar - something long-awaited.

Consequently, analyzing different approaches to the definition of innovation, we came to the conclusion that it should be defined as a product, service, technology or form of organization of human 
activity with signs of novelty, obtained as a result of scientific developments and innovative decisions, and their introduction and / or implementation which give an opportunity to get economic, social, environmental effects.

So, it may be noted that:

1. Innovation is determined depending on the object and subject of research.

2. Innovation gets an incarnation in new or improved products (consumer goods, objects and means of production), technologies, organizational decisions (in this case we consider organizational decisions in the broadest sense as those relating to any sphere of organization of human activity).

3. The basis of innovation is new ideas, scientific developments, innovative solutions.

4. Innovation is a process of change, which leads to the creation of the best, progressive in terms of criteria of socio-economic development of its properties of products, technologies, forms of organization.

5. Innovations provide an opportunity to obtain economic, social, environmental and political effects.

At the same time, the study of community innovations in order to improve welfare is becoming more relevant in startup conditions of decentralization processes in Ukraine.

Unfortunately, Ukraine's quality of life of the population is inferior to many developed countries, which is primarily a consequence of ineffective social policy and, most importantly, the low efficiency of domestic production, which is 3-4 times less than in developed countries. For this reason, it should be emphasized that the modernization of Ukraine's socio-economic policy on innovative principles is the main direction of raising the level and quality of life of the population [16].

Community innovations can be presented as a special form of social innovation based on the field, within the specific geography of the community. Such innovations need to be evaluated as issues that they hope to consider, as well as a deep understanding of the unique characteristics of the community-places and people-where innovation will be introduced.

Given the relevant of the community's problems in terms of development and welfare, it is necessary to create mechanisms aimed at encouraging community-based innovation, as local communities know better their problems and opportunities in their communities.

In addition, public authorities should play a key role in providing local development and community-based innovation. They should also encourage and support initiatives and facilitate access to technology in all its forms, as it is a key factor in achieving the goal. Using technology can help to increase successful initiatives. In the Law of Ukraine "On Investment Activity" innovation activity is considered as one of the forms of investment activity, the main task of which is to use the achievements of scientific and technological progress for production and social sphere, which contains the following components [8]:

1. Issue and distribution of fundamentally new types of engineering and technology; progressive inter-sectoral structural shifts.

2. Implementation of long-term scientific and technical programs with high payback periods of expenses.

3. Financing fundamental research for the implementation of qualitative changes in the state of productive forces.

4. Development and introduction of a new, resource-saving technology, designed to improve the social and environmental situation.

The issue of innovation in the community can be divided into two blocks: innovative scientific and technological activities, innovative activity in the field of public management technologies. The starting point of this issue is the need to adapt its policy towards the adherence of comprehensive economic indicators that reflect the economic, social, demographic, technological, institutional, and ecological state of the country's development [1].

Today, Ukrainian communities are living laboratories for innovation. In every community, ordinary citizens - individuals, neighbors and families - are constantly striving for a better life. The following six elements, shown in Fig.1, are important for innovation capacity. $[6,14]$

Leadership -
demonstrate
commitment to
innovation, articulate
a clear vision and set
of priorities for it,
and give others the
inspiration, freedom,
and support they
need to innovate.

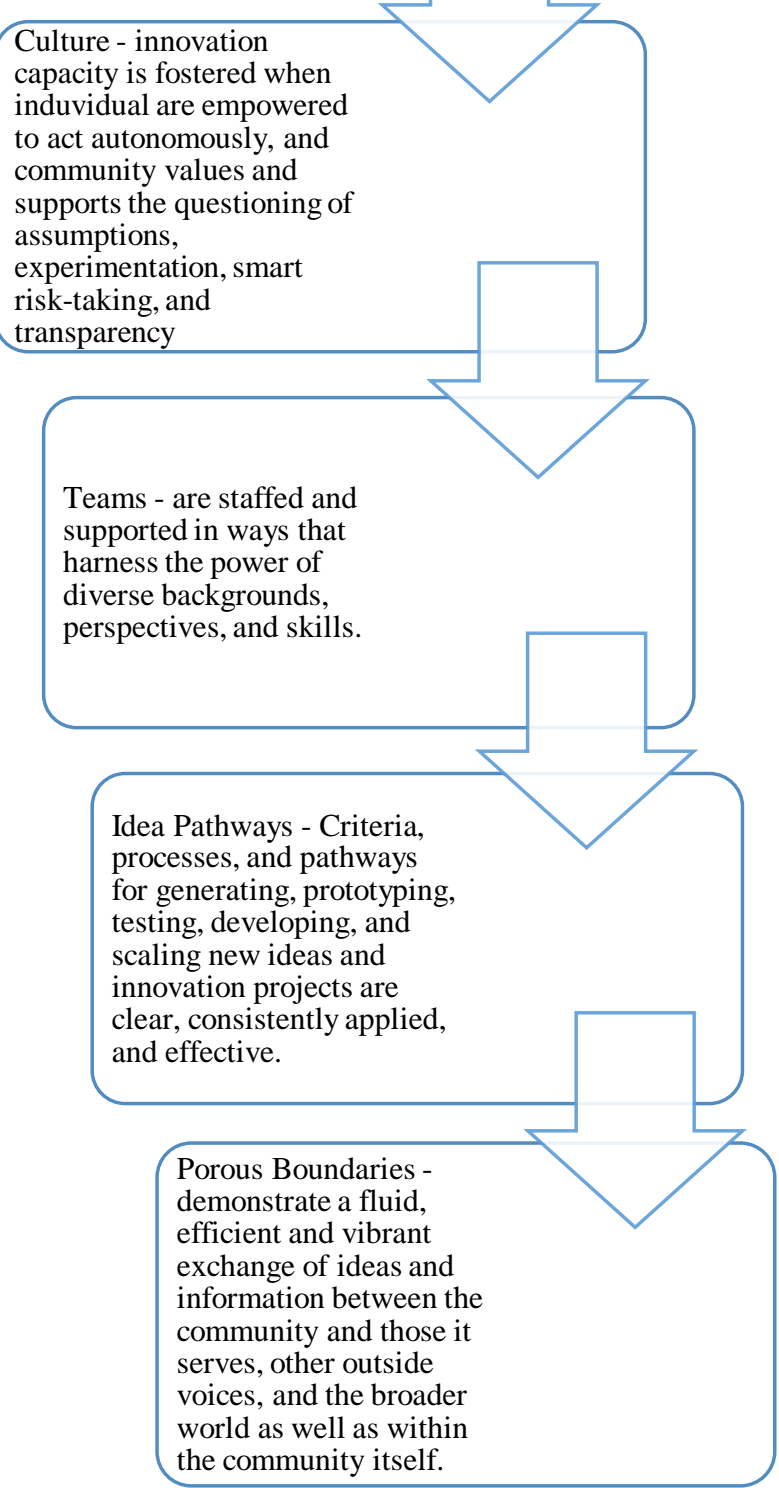

Fig. 1: Elements of innovation capacity.

In practice, 12 principles are outlined that can guide effective work in the field of innovation (Fig.2) [14]. 
Work at scale requires long time lines and strategic intent. With complex problems, balancing focus with adaptability is key to achieving results.

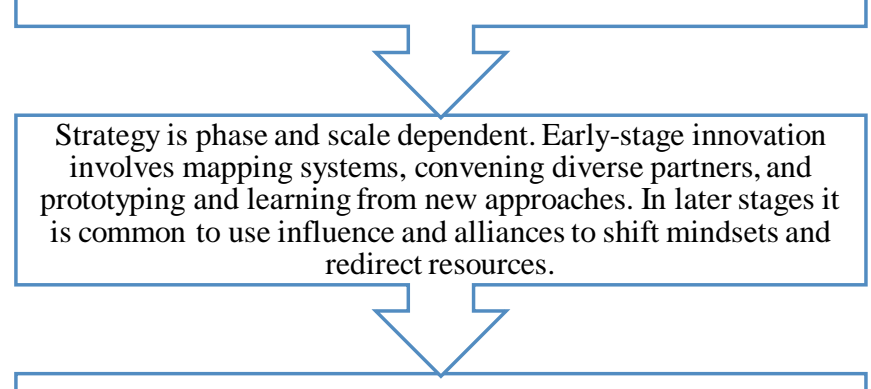

"Listen to the system." As innovations unfold, "surprises" provide valuable clues as to where to place attention.

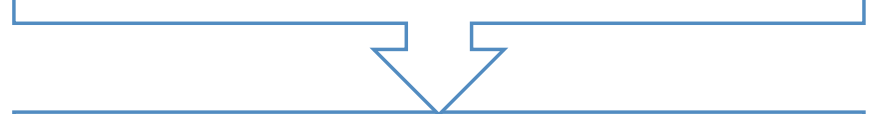

Reflect. When working on innovations, we are often operating outside the norms of conventional practice. Reflection is helpful in documenting decisions taken and linking current strategy to larger purpose.
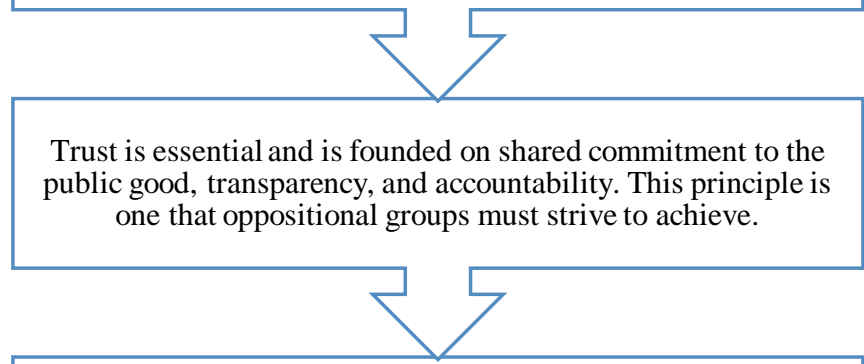

Learn to work across sectors. Inter-sectoral collaboration is a rich source of innovation. Like foreign countries, the community, private and public sectors have language and cultural differences that need to be considered for collaboration to be effective.

Commit to social inclusion. When we include vulnerable populations, including those for whom we are ostensibly working, solution sets are larger, and the results more enduring.

Set minimum specifications when working at multiple sites and multiple levels of scale, allowing partners freedom to adapt.

Share information. Being open and transparent allows unsuspected allies to find us and creates new connections. Working closely with academics links practice to research and accelerates learning and innovation.

Work with diverse professionals. Complex problems yield surprising information when we bring multiple lenses to bear on them. Artists and designers help us to imagine. Engineers can help with restructuring.
The key factor influencing the need for innovation is the competitiveness of the territorial community. Innovations of Ukraine can also be considered as a tool for the development of territorial communities [2].

Any changes in a particular community must take into account its cultural values and, accordingly, any intervention should be carried out in the light of these values. Identify that innovation should be based on the unique values of each community and aimed at their preservation. Such projects mobilize community resources to better serve their members.

In the context of the community, the focus on innovation lies in bottom-up approaches such as grass-roots innovation, innovation in the best business, social innovation and citizen innovation arising from the life of the community, its members, and civil society. It is formed in the sense that the community possesses knowledge about local problems, understands the problem and knows which issues are most relevant.

S. Popov proposed widely known and most generalizing components for the definition of innovation activity (Fig.3) [10].

\begin{tabular}{|c|c|}
$\begin{array}{c}\text { Innovation and } \\
\text { management process, } \\
\text { the life cycle of which } \\
\text { consists of a cycle of } \\
\text { innovation creation and } \\
\text { a cycle of innovation } \\
\text { implementation }\end{array}$ & $\begin{array}{c}\text { The security process, } \\
\text { the basis of which is an } \\
\text { innovative resource, the } \\
\text { degree of readiness of } \\
\text { which is crucial for the } \\
\text { successful } \\
\text { implementation of } \\
\text { innovation activities }\end{array}$ \\
$\begin{array}{c}\text { "Feedback" through the } \\
\text { transfer of information } \\
\text { on the implications of } \\
\text { the innovations' } \\
\text { introduction and the } \\
\text { emergence of new } \\
\text { development needs } \\
\text { through dichotomy } \\
\text { "practice - science" }\end{array}$ & $\begin{array}{c}\text { Types and ways of } \\
\text { escorting in the field of } \\
\text { development of } \\
\text { innovative culture, } \\
\text { methodological escorte, } \\
\text { technological support } \\
\text { (use of various kinds of } \\
\text { information and } \\
\text { communication - social } \\
\text { technologies) }\end{array}$ \\
\hline
\end{tabular}

Fig. 3: Ingredients of innovation activity.

In addition to the principles, can be noted the elements, which need to be taken into account in developing an infrastructure that encourages and supports innovation, such as ideas, skills, tools, financing and structural elements.

According to the experts of the Rockefeller Foundation, "in order to bring effective innovation in the long run, organizations (and communities) need to establish a process and structure that will define clear ways to develop new ideas and ensure the most efficient use of resources" [14].

To the principles of innovation in our work we include:

- study of the development perspectives of sales markets and the customers' opinions about unsatisfied needs, purchased products;

- promotion of new products to the market (preparation of exhibitions-sales, organization of fairs and other promotional actions);

- reasoning of prices for innovative products, possible convenient calculation schemes;

- interaction with public administration bodies for the implementation of state and international target programs;

- - preparation of contracts for the products' supply;

- preparation of analytical materials, forecasts, plans and sales of products;

Fig. 2: Elements of the infrastructure of innovations. 
- formation of a new commodity network (creation of dealer and distribution centers);

- coordination of the creation and certification of service centers;

- establishment of business relations in other regions;

- formation of an advertising strategy, development of advertising avenues, catalogs of products, souvenir advertising products;

- organization of presentations, press conferences, receptions and meetings, others.
To determine the functions to be implemented by the innovation management and obtaining the result on the basis of the existing innovative potential, we will proceed from the presentation of the investigated process as a three-dimensional space with coordinates "innovative potential - innovation process - innovation result" (Fig. 4) [5, 6].
The function of the integrated assessment of use degree of innovative potential and its transformation into various public goods is expressed through the improvement of management (application of innovative management approaches, methods, models, technologies, etc.), and through indirect influence (raising the level and quality of communities' life).

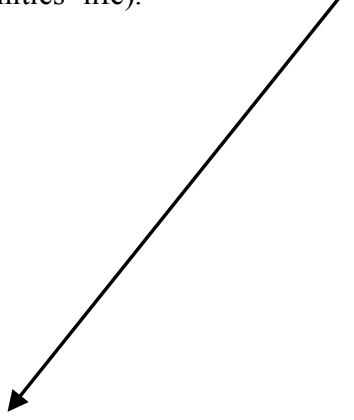

\section{Innovation result}

\section{$\hat{1}$}

Management is an anti-crisis function (integral function of riskoriented strategic management) in the course of which transition management is implemented.

The function of monitoring and feedback is carried out with the complexity of innovation and management processes.

The function of the management tool for performing the first two specified functions.

The function of communicative provision of managerial innovation processes (information and communicative function) is necessary in the new conditions for the formation and development of society
Innovation process function is to form an innovative basis for developing a development strategy for the territorial community, which results in absolute innovations (new knowledge leading to scientific and technological progress) and relative innovations (adaptation of knowledge-specific processes, resources, infrastructure for the economy).

The task of innovation infrastructure function is institutionalizing innovation activities in the territory, and as a result, create a proper innovation infrastructure of the territory.

Innovative potential

Fig. 4: Management Functions of innovative development of territorial communities.

That is, the "innovative potential - innovation process" area presents the "entrance" of the system and generates, first of all, the processes of reproduction (formation, support, build-up) of innovative potential. The "innovative potential - innovation results" area presents changes (change gradients) of the "output" of the system in comparison with the "input".

Thus, the factors for introducing innovations in industries, organizations or communities are:

1) taking into account innovations in the formation of scientific, technological and innovation policy;

2) creation of democratic platforms in order to attract various economic entities;

3) ensuring proper coordination, integration and reflection of activities in national and regional socio-economic plans and programs;

4) increase of investment volume in the development of innovative potential;

5) stimulation of holding research in the field of innovation;

6) mutually beneficial partnership of the state, communities and business in support of innovation. [4].

\section{Conclusion}

So, we believe that community innovations perform such basic functions based on the definition of "innovation" and analyzing the work of scientists in this field:

1. Reproductive: involves expanded reproduction through improved conditions of production, capture and retention of markets.

2. Investment: the profit earned through the implementation of innovation, can be used in various directions, including for further investment.

3. Stimulating: receiving an entrepreneur with additional profits through the implementation of innovations serves as an incentive for the introduction of new innovations; prompts constantly to study demand, to improve the organization of marketing activities, to apply modern methods of management.

4. Social: innovations provide an opportunity to improve the quality of products, technologies and forms of activity 
organization, to increase productivity, to ease its difficulty and to improve conditions.

5. Environmental: innovations enable to reduce environmental pollution and to organize environmentally safe production processes.

6. Educational and cognitive: generation of innovations leads to the emergence of new knowledge, their implementation requires additional training of enterprises' employees.

Consideration of innovation functions indicates its complex nature, which characterizes innovation activity as rather complex and versatile. Management of innovative activities requires a serious development and a well-founded classification of innovations.

The starting point for a sustainable society is the rise of community qualifications, abilities and knowledge.

With the help of innovation, business entities and territorial communities can solve certain tasks for their further development, such as: improving the efficiency of enterprises and social sector organizations, improving the quality of social services through improved compliance with constantly changing society requirements that constantly changing; reducing social inequality by increasing the accessibility of services that provided, the inclusion of those community members with special needs.

At that, the implemented decentralization reform is a help in the development of innovations to individual economic entities and communities as a whole, which is a prerequisite for improving the investment climate in Ukraine. Among other things, decentralization involves cooperation with foreign investors and international financial organizations that wish to implement specific projects in Ukraine. That is, the development of innovation can be considered the basis of a wealthy and prosperous territorial community and the entire business, and the main feature of innovation is their focus on improving the welfare of people in the community.

\section{References}

[1] Abramov L.K., Center for Local Activities for Community Development, ISKM, (2012), p:144.

[2] Artemenko A.G. (2016), Innovations in the system of local selfgovernment as a means of managing the development of territorial communities. KhNTU, $76-80$.

[3] Balabanov I.T., Innovative Management, Publishing House "Peter", (2005), p: 208.

[4] Bolotna O.V. (2017), Social Innovations as an Instrument for Improving the Quality of Life of the Population of Ukraine. Mukachevo State University Issue, 510-517.

[5] Chikarenko I.A. (2015) Integrated model of management system for innovative development of territorial communities. Regional and Municipal Management, 81 - 90.

[6] Chikarenko I.A., Formation of management system for innovative development of territorial communities: monograph, DREAD NADY, (2014), p: 338.

[7] Law of Ukraine "On Innovative Activities", Revision dated 05/12/2012, available online: http://zakon3.rada.gov.ua/laws/show/40-15, last visit: 17.06.2018.

[8] Law of Ukraine "On Investment Activity" Revision dated 18/09/1991, available online: www.rada.gov.ua, last visit: 17.06.2018.

[9] Peresunko ZM, "Theoretical Aspects of the Development of the Innovation Theory", Electronic Scientific Special Edition "Effective Economy", Vol.12, No.7, (2013), pp:84-89, http://www.economy.nayka.com.ua/?op=1\&z=2192.

[10] Popov SA, State-management innovations: theory, methodology, practice, monograph, ORIDY NADY, (2014), p: 82-83.

[11] Rumyantsev N.A., Scientific and innovation sphere in the region problems and prospects of development, Nauka, (1996), p: 194

[12] Schumpeter I., Theory of Economic Development: research of entrepreneurial profit, capital, credit and the cycle of conjuncture, Progress, (1982), p: 455.

[13] Smith A., "Research on the nature and causes of wealth of peoples", available online: https://www.ereading.club/book.php?book=100806, last visit: 18.06.2018.

[14] Stephen Huddart, "Patterns, principles, and practices in social innovation”, The Philanthropist, Vol.23, No.3, (2010), pp: 221-234,
https://thephilanthropist.ca/original-pdfs/Philanthropist-23-3422.pdf.

[15] Sumets O.M., Commodity Innovation Policy, Hi-Tech Press, (2012), p: 368.

[16] The legatum prosperity index (2016) Bringing Prosperity to Life, available online: http://www.prosperity.com/rankings, last visit: 16.06.2018.

[17] Tugan-Baranovskaya M.I. Political Economy, Scientific thought, (1994), p: 264.

[18] Twice Brian, Management of Science and Technology Innovations, Economics, (1989), p: 271.

[19] Wang S., Heisey P., Schimmelpfennig D. \& Ball E., “Agricultural Productivity Growth in the United States: Measurement, Trends, and Drivers", USDA ERS, (2015), http://www.ers.usda.gov/amberwaves/2015-september/us-agricultural-productivity-growth-thepast,-challenges,-and-the-future.aspx\#.Vr8zPrSLTMw. 